\title{
Pemanfaatan Global Positioning System (GPS) Untuk Menghitung Panjang Dan Luas Lahan
}

\author{
Utilization of Global Positioning System (GPS) To Calculate Length and Area of Land
}

\author{
Andrew Stefano* \\ Program Studi Teknologi Geomatika, Politeknik Pertanian Negeri Samarinda \\ Kampus Gunung Panjang Jl. Samratulangi Samarinda 75131, Indonesia.
}

${ }^{*}$ Correspondence Author: andrew.stefano@politanisamarinda.ac.id

\begin{abstract}
Abstrak
Menghitung luas tanah dapat dilakukan dengan beberapa metode, salah satunya menggunakan metode titik koordinat. Titik koordinat digunakan sebagai patokan untun menentukan luas tanah. Kelebihan dari perhitungan menggunakan titik koordinat adalah kecepatan proses perhitungan dan biaya yang dikeluarkan tidak begitu besar. Aplikasi menghitung panjang dan luas tanah menggunakan GPS (Global Positioning System) merupakan aplikasi yang dapat membantu pengguna smartphone untuk menghitung luas tanah. Pengembangan aplikasi Luas Tanah ini menggunakan pendekatan prototype. Aplikasi Luas Tanah ini memanfaatkan fasilitas dari Google Map API, yang menerapkan system client- server, terdiri dari sisi server sebagai penyedia dan pengelola informasi dan sisi client sebagai pengguna informasinya.
\end{abstract}

Kata Kunci : Android, GPS, Luas Tanah.

\begin{abstract}
Calculating land area can be done by several methods, one of which is using the coordinate point method. The coordinates are used as a benchmark to determine the land area. The advantages of calculations using point coordinates are the speed of the calculation process and the costs incurred are not so large. The application to calculate the length and area of land using GPS (Global Positioning System) is an application that can help smartphone users to calculate land area. The development of this Land Area application uses a prototype approach. This land area application utilizes the facilities from the Google Map API, which implements a client-server system, consisting of the server side as the provider and manager of information and the client side as the information user.
\end{abstract}

Keywords: Android, GPS, Land Area.

\section{PENDAHULUAN}

Tanah merupakan salah satu sumber daya alam yang penting untuk kelangsungan hidup umat manusia (Abdolkarimi et al., 2020; Barefoot et al., 2019; Crawford \& Mort, 2017). Hubungan manusia dengan tanah bukan hanya sekedar tempat hidup, tetapi lebih dari itu karena tanah memberikan sumber daya bagi keberlangsungan hidup umat manusia (Dorothea et al., 2020; Elsaied et al., 2019; Grobler et al., 2019). Mendefinisikan tanah sebagai akumulasi tubuh alam bebas, menduduki sebagain besar permukaan planet bumi, yang mampu menumbuhkan tanaman, dan memiliki sifat sebagai akibat pengaruh iklim dan jasad hidup yang bertindak terhadap bahan induk dalam keadaan relief tertentu selama jangka waktu tertentu pula (Huang et al., 2017; Jamil et al., 2020; Janicka et al., 2020).

Dalam bidang pertanahan, sebidang tanah memiliki fungsi sesuai dengan tujuan penggunaannya, misalnya dipergunakan untuk membangun sarana umum, perumahan dan lain-lain seperti tertuang pada UU RI Nomor 26 Tahun 2007 Tentang Penataan Ruang. Secara umum dalam pelaksanaan pembangunan sarana umum tersebut proses perhitungan luas tanah sangat penting (Kadereit, 2017; Katapally et al., 2020; Khan et al., 2018). Perhitungan luas dilakukan untuk pemindahan hak dari pihak kesatu ke pihak kedua (Lißner et al., 2020; Liu et al., 2019; Lizurek \& Crespi, 2021).

Proses perhitungan tanah yang sebelumnya dilakukan dengan cara menarik meteran untuk menentukan 
jaraknya dan menggunakan buku millimeter blok untuk media penggambarannya masih memiliki kekurangan dari seri waktu yang cukup lama dan biaya yang lebih lama (Mascitelli et al., 2020; Poliziani et al., 2020; Prikryl et al., 2020).

Perkembangan teknologi informasi berperan penting dalam berbagai sektor kehidupan manusia dan dapat dimanfaatkan dalam bidang pertanahan. Teknologi informasi yang terus berkembang sampai sekarang adalah mobile phone (Shimna \& Muthu, 2020; Si et al., 2020; Sophia et al., 2020). Dahulu mobile phone hanya bisa digunakan untuk komunikasi suara, tetapi sekarang kemampuan mobile phone sudah sangat canggih, dimana pekerjaan yang dulunya hanya bisa dilakukan oleh komputer sekarang dapat dilakukan oleh mobile phone. Mobile phone jenis ini dikenal oleh masyarakat luas dengan sebutan smartphone (Svetlana et al., 2019; Teickner et al., 2020; Uehara et al., 2020).

Android adalah salah satu sistem operasi yang digunakan pada smartphone yang cukup populer saat ini karena menyediakan layanan GPS (Global Positioning System). GPS (Global Positioning System) adalah suatu sistem navigasi satelit yang terdiri dari 24 satelit beroperasi dan 3 satelit cadangan. Ke-24 satelit itu mengorbit bumi pada jarak 20.200 $\mathrm{km}$ dan waktu orbit 12 jam, sambil memancarkan sinyal berita gelombang radio yang diterima oleh alat penerima (receiver) (Verdú et al., 2019; B. Wang \& Wang, 2019; Q. Wang et al., 2020).

Dengan adanya GPS, proses menghitung luas tanah lebih cepat dengan cara menentukan koordinat dari titik-titik yang sudah ditentukan sebelumnya ( $\mathrm{Yi}$ et al., 2020; Zhang et al., 2020; Zhu et al., 2020). Titik kordinat tersebut digunakan sebagai acuan untuk perhitungan. Informasi yang dihasilkan akan lebih cepat karena titik koordinat yang sebelumnya sudah disimpan akan dimunculkan di dalam peta (Woldemariam et al., 2018; Xie et al., 2020; Ye et al., 2019). Berdasarkan latar belakang masalah diatas, maka ruang lingkup penelitian ini adalah bagaimana membangun sebuah aplikasi yang mampu menghitung panjang dan luas tanah menggunakan GPS sebagai inputnya pada perangkat Smartphone berbasis Android.
Tujuan penelitian ini adalah membangun sebuah aplikasi untuk memudahkan pengguna (user) dalam menghitung panjang dan luas tanah yang memanfaatkan GPS pada smartphone berbasis Android. Sedangkan manfaat yang diharapkan dari penelitian ini adalah terciptanya sebuah aplikasi yang mampu menghitung luas tanah menggunakan GPS sebagai inputnya pada perangkat Smartphone berbasis Android, yang diharapkan mampu menghemat biaya pengukuran panjang dan luas tanah(Woldemariam et al., 2018; Xie et al., 2020; Ye et al., 2019).

\section{METODE PENELITIAN}

Metodologi Penelitian yang digunakan dalam mengembangkan Aplikasi Kebudayaan Indonesia ini mengacu pada keilmuan Rekayasa Perangkat Lunak (Software Engineering), dalam hal ini System Development Life Cycle (SDLC) dengan pendekatan model Prototype. Adapun tahapan pendekatan model Prototype yang digunakan dibagi menjadi beberapa tahapan, yaitu:

Dalam tahap pertama pembuatan aplikasi ini adalah bertemu dengan developer tanah untuk membahas masalah yang dihadapi oleh developer dalam proses menghitung luas tanah dan mengumpulkan data-data agar aplikasi dapat berjalan sesuai dengan kebutuhan devepoler. Bila semua data berhasil dikumpulkan maka dibuatlah analisis kebutuhan seperti kebutuhan pengguna, kebutuhan fungsional, kebutuhan nonfungsional, kebutuhan perangkat lunak dan kebutuhan perangkat keras (Verdú et al., 2019; B. Wang \& Wang, 2019; Q. Wang et al., 2020).

Tahapan selanjutnya dalam model prototype ini adalah membuat mock-up. Berdasarkan data yang sudah didapatkan, perancangan seperti membuat diagram Usecase, diagram kelas, diagram sekuen, diagram aktivitas, database, design userinterface. Setelah analisis dan design selesai, pengembang melanjutkan ke proses pengkodingan aplikasi dengan mengunakan analisis tersebut sebagai acuan agar aplikasi yang dibuat sesuai dengan yang diharapkan. Developer tanah mengevaluasi prototype yang dibuat dan 
digunakan untuk memperjelas kebutuhan software. Ketika developer tanah merasa puas atas prototype yang dibangun, maka kebutuhan sistem telah tergambarkan seluruhnya dan sistem siap dikembangkan menjadi perangkat lunak (Svetlana et al., 2019; Teickner et al., 2020; Uehara et al., 2020).

\section{HASIL DAN PEMBAHASAN}

Ilmu ukur tanah tanah merupakan ilmu, seni, dan teknologi untuk menyajikan bentuk permukaaan bumi baik unsur alam maupun unsur buatan manusia pada bidang yang dianggap datar. Pengukuran tanah adalah sebuah pekerjaan mudah akan tetapi jika pelaksanaannya kurang hati-hati dapat menimbulkan kesalahan. Sebelum membangun suatu tempat proses mengukur tanah harus dilakukan terlebih dahulu, hasil pengukuran tanah inilah yang nantinya digunakan untuk membuat desain tempat secara lengkap. Data pengukuran tanah yang diperlukan antara lain:

- Panjang dan lebar tanah.

- Luas tanah.

- Posisi tanah dengan jalan raya dan bangunan disekitarnya.

- Bentuk tanah.

- Tinggi permukaan tanah dari jalan raya atau muka air banjir setempat.

Titik-titik dasar teknik diperlukan sebagai kerangka dasar referensi nasional. Secara sederhana dapat dijelaskan bahwa titik-titik ini diperlukan untuk pemetaan bidang tanah secara nasional, di mana letak, ukuran, luas dan dimensi lain dari suatu bidang tanah dapat diketahui dan direkonstruksi secara tepat dan akurat. Tingkatan titik dasar teknik dibagi menjadi lima tingkatan, yaitu: titik dasar orde 0 , orde 1 , orde 2 , orde 3 , dan orde 4 . Titik dasar orde 0 dan 1 dilaksanakan dan dibangun oleh Badan Koordinasi Survey dan Pemetaan Nasional (BAKOSURTANAL).

Titik dasar orde 2 dan 3 dilaksanakan oleh BPN Pusat, sedangkan titik dasar orde 3 dapat dilaksanakan oleh Kantor Wilayah BPN Propinsi, dan titik dasar orde 4 umumnya dilaksanakan oleh Kantor Pertanahan Kabupaten/Kota. Pengukuran titik dasar teknik orde 2, 3, dan 4 dilaksanakan dengan menggunakan metoda pengamatan satelit atau metoda lainnya. Metoda yang dimaksud adalah penentuan posisi dengan Global Positioning System (GPS). Sedangkan penetapan titik dasar teknik orde 4 umumnya dilaksanakan melalui pengukuran terestris dengan cara perapatan dari titik-titik dasar orde 3 .

Menurut PMNA/KaBPN No. 3 (1997), melalui pengikatan kepada titik-titik dasar orde 4, maka dilaksanakan pengukuran tanah bidang per bidang. Bidang-bidang tanah hasil pengukuran kemudian dipetakan dalam Peta Dasar Pendaftaran. Peta ini berskala 1:1000 atau lebih besar untuk daerah perkotaan, 1:2500 atau lebih besar untuk daerah pertanian, dan

1:10000 atau lebih kecil untuk daerah perkebunan besar. Peta ini harus mempunyai ketelitian planimetris lebih besar atau sama dengan $0,3 \mathrm{~mm}$ pada skala peta.

Sebelum suatu bidang tanah diukur, wajib dipasang dan ditetapkan tanda-tanda batasnya, setelah mendapat persetujuan dari pemilik tanah yang berbatasan langsung. Apabila sampai dilakukannya penetapan batas dan pengukuran bidang tanah tidak tercapai kesepakatan mengenai batas-batasnya (terjadi sengketa batas), maka ditetapkan batas sementara yang menurut kenyataannya merupakan batas bidang-bidang tanah yang bersangkutan. Pengukuran bidang tanah dapat dilakukan secara terestrial, fotogrametrik, atau metoda lainnya.

Pengukuran terestris adalah pengukuran dengan menggunakan alat ukur theodolite berikut perlengkapannya seperti: pita ukur, baak ukur, electronic distance measurement (EDM), GPS receiver, dan lain sebagainya. Adapun pemetaan secara fotogrametrik adalah pemetaan melalui foto udara (periksa foto simulasi di atas). Hasil pemetaan secara fotogrametrik berupa peta foto tidak dapat langsung dijadikan dasar atau lampiran penerbitan Sertipikat Hak atas Tanah. Pemetaan secara fotogrametrik tidak dapat lepas dari referensi pengukuran secara terestris, mulai dari penetapan ground controls (titik dasar kontrol) hingga kepada pengukuran batas tanah. Batas-batas tanah yang diidentifikasi pada peta foto harus diukur di lapangan.

Langkah-langkah pengukuran tanah secara manual dilapangan dapat diuraikan 
sebagai berikut:

- Membersihkan lahan dari rintangan yang akan menghalangi pengukuran, untuk mengatasinya dapat digunakan rumus pengukuran tanah dengan membuat garis pinjaman di lahan tanah kosong.

- Mengukur panjang dan lebar tanah dengan roll meter atau teodholit.

- Mengukur sudut tanah dengan menggunakan teodholit maupun mengukur sudut sederhana.

- Mengukur lebar jalan raya.

- Mengukur bangunan yang ada di sekitar lahan tanah rencana pembangunan tempat.

Metode penentuan posisi adalah cara untuk mendapatkan informasi koordinat suatu objek (contoh koordinat titik batas, koordinat batas persil tanah dan lain-lain) di lapangan. Metoda penentuan posisi dapat dibedakan dalam dua bagian, yaitu metoda penentuan posisi terestris dan metoda penentuan posisi extra-terestris (satelit). Pada metoda terestris penentuan posisi titik dilakukan dengan melakukan pengamatan terhadap target atau objek yang terletak di permukaan bumi. Beberapa contoh metoda yang umum digunakan adalah:

- Metode poligon.

- Metode pengikatan ke muka.

- Metode pengikatan ke belakang.

Luas suatu daerah adalah proyeksi luas di atas permukaan bumi pada bidang mendatar yang dikelilingi oleh garis-garis batas. Latitude adalah garis yang melintang di antara kutub utara dan kutub selatan, yang menghubungkan antara sisi timur dan barat bagian bumi. Garis ini memiliki posisi membentangi bumi, sama halnya seperti garis equator (khatulistiwa), tetapi dengan kondisi nilai tertentu. Garis lintang inilah yang dijadikan ukuran dalam mengukur sisi utara-selatan koordinat suatu titik di belahan bumi. Latitude di bedakan menjadi 2 wilayah, yaitu utara atau yang biasa kita sebut lintang utara dan selatan atau yang biasa kita sebut lintang selatan, dimana nilai koordinat di bagian utara selalu positif dan nilai koordinat di bagian selatan adalah negatif.

Longitude adalah garis membujur yang menghubungkan antara sisi utara dan sisi selatan bumi (kutub). Garis bujur ini digunakan untuk mengukur sisi barat-timur koordinat suatu titik di belahan bumi. Sama seperti equator pada latitude yang berada ditengah dan memiliki nilai 0 (nol) derajat, pada longitude, garis tengah yang bernilai 0 (nol) derajat disebut garis prime meridian (garis bujur). Sedangkan garis yang berada paling kiri memiliki nilai 90 derajat, dan yang paling kanan memiliki nilai 90 derajat. Longitude juga dibedakan menjadi 2 wilayah, yaitu bujur timur dan bujur barat, dimana koordinat yang berada di timur selalu bernilai negatif, dan sebaliknya yang berada di barat selalu positif. Nilai satuan ukuran derajat menjadi kilometer pada longitude juga sama seperti pada latitude.

Jadi, dalam metode pengukuran koordinat, suatu titik terlebih dulu diukur derajatnya berdasarkan latitude dan longitude-nya, setelah itu barulah di translasikan kedalam bentuk satuan desimal maupun degree-minutes-second (DMS). Seperti yang tercatat oleh Svennerberg (Beginning Google Maps API 3), Google Maps API adalah API yang paling populer di internet. Pencatatan yang dilakukan pada bulan Mei tahun 2015 ini menyatakan bahwa 43\% mashup (aplikasi dan situs web yang menggabungkan dua atau lebih sumber data) menggunakan Google Maps $A P I$. Beberapa tujuan dari penggunaan Google Maps API adalah untuk melihat lokasi, mencari alamat, mendapatkan petunjuk mengemudi dan lain sebaginya. Hampir semua hal yang berhubungan dengan peta dapat memanfaatkan Google Maps.

Google Maps (tanpa API) diperkenalkan pada Februari 2005 dan merupakan revolusi bagaimana peta di dalam halaman web, yaitu dengan membiarkan user untuk menarik peta sehingga dapat menavigasinya. Solusi peta ini pada saat itu masih baru dan membutuhkan server khusus. Beberapa saat setelahnya, ada yang berhasil men-hack Google Maps untuk digunakan di dalam webnya sendiri. Hal ini membuat Google Maps mengambil kesimpulan bahwa mereka membutuhkan API dan pada Juni 2005, Google Maps API dirilis secara publik.

Menurut Andre (2009), Sistem Pemosisi Global atau Global Positioning System (GPS) adalah sistem untuk menentukan letak di permukaan bumi dengan bantuan penyelarasan (synchronization) sinyal satelit. Sistem ini 
menggunakan 24 satelit yang mengirimkan sinyal gelombang mikro ke Bumi. Sinyal ini diterima oleh alat penerima di permukaan, dan digunakan untuk menentukan letak, kecepatan, arah, dan waktu. Sistem ini menggunakan sejumlah satelit yang berada di orbit bumi, yang memancarkan sinyalnya ke bumi dan ditangkap oleh sebuah alat penerima. Ada tiga bagian penting dari sistim ini, yaitu bagian kontrol, bagian angkasa, dan bagian pengguna.

Fungsi bagian ini untuk mengontrol setiap satelit dapat berada sedikit diluar orbit, sehingga bagian ini melacak orbit satelit, lokasi, ketinggian, dan kecepatan. Sinyalsinyal dari satelit diterima oleh bagian kontrol, dikoreksi, dan dikirimkan kembali ke satelit. Koreksi data lokasi yang tepat dari satelit ini disebut dengan data ephemeris, yang nantinya akan di kirimkan kepada alat navigasi. Bagian ini terdiri dari kumpulan satelit-satelit yang berada di orbit bumi, sekitar 12.000 mil diatas permukaan bumi. Kumpulan satelit-satelit ini diatur sedemikian rupa sehingga alat navigasi setiap saat dapat menerima paling sedikit sinyal dari empat buah satelit. Sinyal satelit ini dapat melewati awan, kaca, atau plastik, tetapi tidak dapat melewati gedung atau gunung. Satelit mempunyai jam atom, dan juga akan memancarkan informasi waktu/jam.

Data ini dipancarkan dengan kode 'pseudo-random'. Masing-masing satelit memiliki kodenya sendiri-sendiri. Nomor kode ini biasanya akan ditampilkan di alat navigasi, maka kita bisa melakukan identifikasi sinyal satelit yang sedang diterima alat tersebut. Data ini berguna bagi alat navigasi untuk mengukur jarak antara alat navigasi dengan satelit, yang akan digunakan untuk mengukur koordinat lokasi. Kekuatan sinyal satelit juga akan membantu alat dalam penghitungan. Kekuatan sinyal ini lebih dipengaruhi oleh lokasi satelit, sebuah alat akan menerima sinyal lebih kuat dari satelit yang berada tepat diatasnya (bayangkan lokasi satelit seperti posisi matahari ketika jam 12 siang) dibandingkan dengan satelit yang berada di garis cakrawala (bayangkan lokasi satelit seperti posisi matahari terbenam/terbit).

Ada dua jenis gelombang yang saat ini dipakai untuk alat navigasi berbasis satelit pada umumnya, yang pertama lebih dikenal dengan sebutan L1 pada $1575.42 \mathrm{MHz}$. Sinyal L1 ini yang akan diterima oleh alat navigasi. Satelit juga mengeluarkan gelombang L2 pada frekuensi 1227.6 Mhz. Gelombang L2 ini digunakan untuk tujuan militer dan bukan untuk umum. Bagian ini terdiri dari alat navigasi yang digunakan. Satelit akan memancarkan data almanak dan ephemeris yang akan diterima oleh alat navigasi secara teratur.

Data almanak berisikan perkiraan lokasi (approximate location) satelit yang dipancarkan terus menerus oleh satelit. Data ephemeris dipancarkan oleh satelit, dan valid untuk sekitar 4-6 jam. Untuk menunjukkan koordinat sebuah titik (dua dimensi), alat navigasi memerlukan paling sedikit sinyal dari 3 buah satelit. Untuk menunjukkan data ketinggian sebuah titik (tiga dimensi), diperlukan tambahan sinyal dari 1 buah satelit. Dari sinyal-sinyal yang dipancarkan oleh kumpulan satelit tersebut, alat navigasi akan melakukan perhitungan-perhitungan, dan hasil akhirnya adalah koordinat posisi alat tersebut. Makin banyak jumlah sinyal satelit yang diterima oleh sebuah alat, akan membuat alat tersebut menghitung koordinat posisinya dengan lebih tepat.

Perhitungan luas tanah sangat penting dalam proses pemindahan hak kepilikan tanah. Sebelumnya perhitungan dilakukan dengan cara manual yaitu : Pengambilan data menggunakan meteran dan media penggambaran menggunakan kertas milimeter blok dan jangka, masih memiliki kekurangan dari segi waktu dan biaya. Oleh karena itu pembuatan aplikasi perhitungan luas menggunakan GPS ini bisa membantu developer tanah dalam melakukan proses perhitungan tanah menjadi lebih cepat dalam mendapatkan informasi sehinggan biaya yang dikeluarkan tidak membengkak.

Perancangan Aplikasi Luas Tanah ini terdiri dari dua system, yaitu server side dan client side. Maka arsitektur fisik sistem terdiri dari tiga komponen utama yaitu aplikasi mobile, aplikasi Server dan database Server. Arsitektur sistem dalam pembangunan Aplikasi perhitungan luas ini dtitunjukan oleh Gambar 3 di bawah ini. 


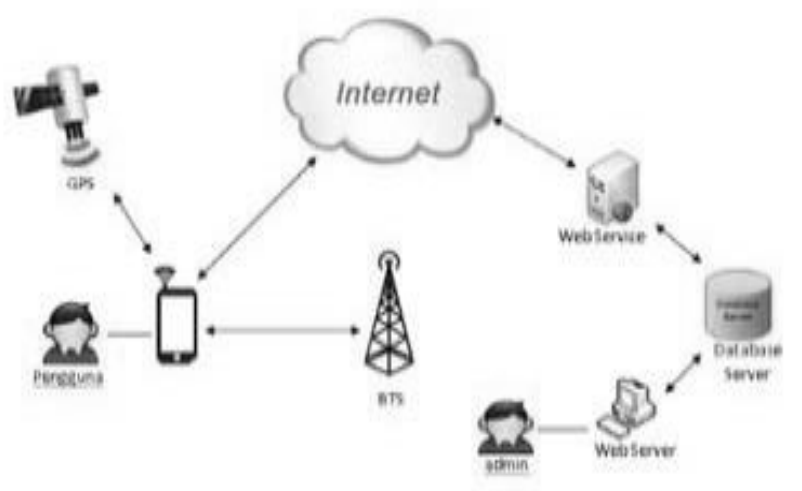

Gambar 1. Arsitektur Aplikasi Perhitungan Luas Tanah (Abdolkarimi et al., 2020)

Untuk mengetahui lokasi posisi pengguna memanfaatkan GPS yang dapat menangkap koordinat longitude dan latitude. Aplikasi mobile yaitu Aplikasi perhitungan luas tanah yang sudah terinstal pada perangkat mobile yang ber-platform Android. Bagian ini berfungsi sebagai antarmuka yang menghubungkan antara pengguna dengan sistem. Pengembangan antarmuka sistem dibangun dengan menggunakan Aplikasi IDE Eclipse dan SDK android dengan bahasa pemrogramam java.

Aplikasi server merupakan aplikasi yang menghubungkan antara aplikasi frontend dengan database server. Web Administrator merupakan web yang berfungsi sebagai pengolah sumber basis data yang terdapat pada database server yang dioperasikan oleh admin. Aplikasi
Server ini dibangun dengan menggunakan bahasa pemrograman PHP. Webservice merupakan web yang bertujuan untuk menguhubungkan berbagai platform aplikasi yang dibangun dengan berbagai platform yang berbeda, sehingga seluruh aplikasi tersebut dapat saling berkomunikasi. Web service pada penelitian ini dibangun diatas pemrograman PHP yang dikombinasikan dengan JSON (Javascript Object Notation). Database Server merupakan aplikasi yang berfungsi menyimpan data-data yang digunakan oleh layanan (Admin). Pada bagian ini di implementasikan menggunakan MySQL. Aplikasi ini menggunakan struktur navigasi Hierarchical Model. Seperti pada gambar dibawah ini, sebelum masuk ke menu utama user harus terkoneksi internet.

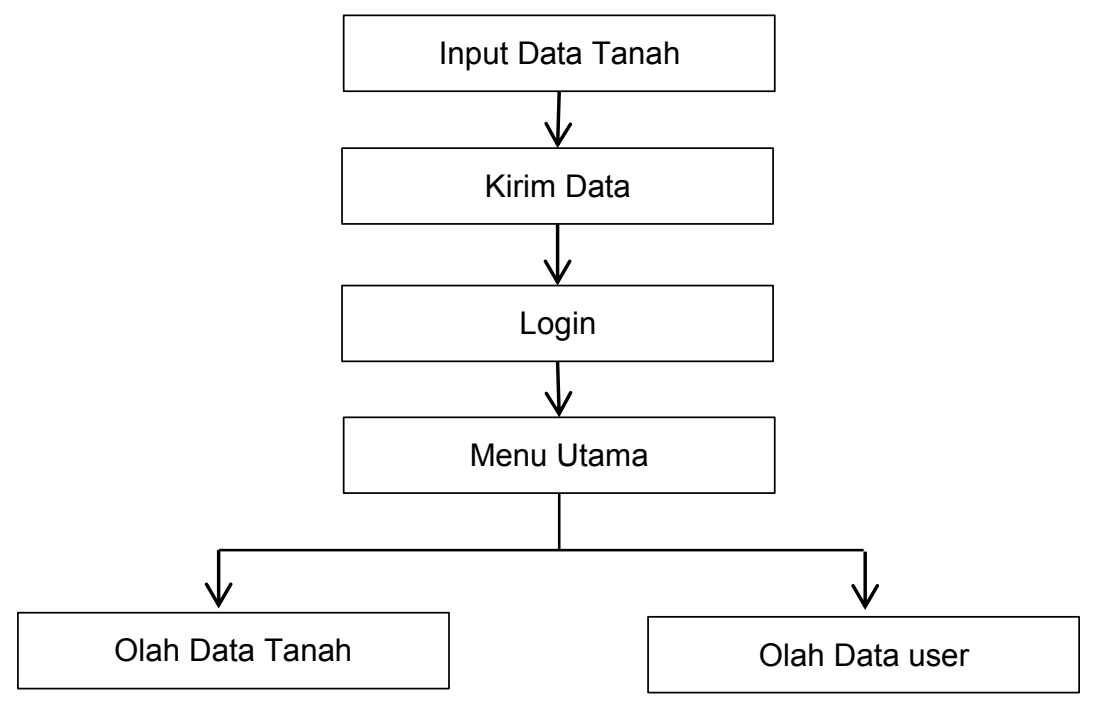

Gambar 2. Perancangan Navigasi Bagian Mobile (Barefoot et al., 2019) 
Class diagram merupakan suatu diagram yang menggambarkan atau memvisualisasikan struktur sistem dari kelas-kelas serta hubungannya. Struktur
Aplikasi berdasarkan class diagram memiliki tujuan untuk menampilkan interaksi dalam kelas-kelas tersebut, atribut dan metode yang dimiliki kelas.

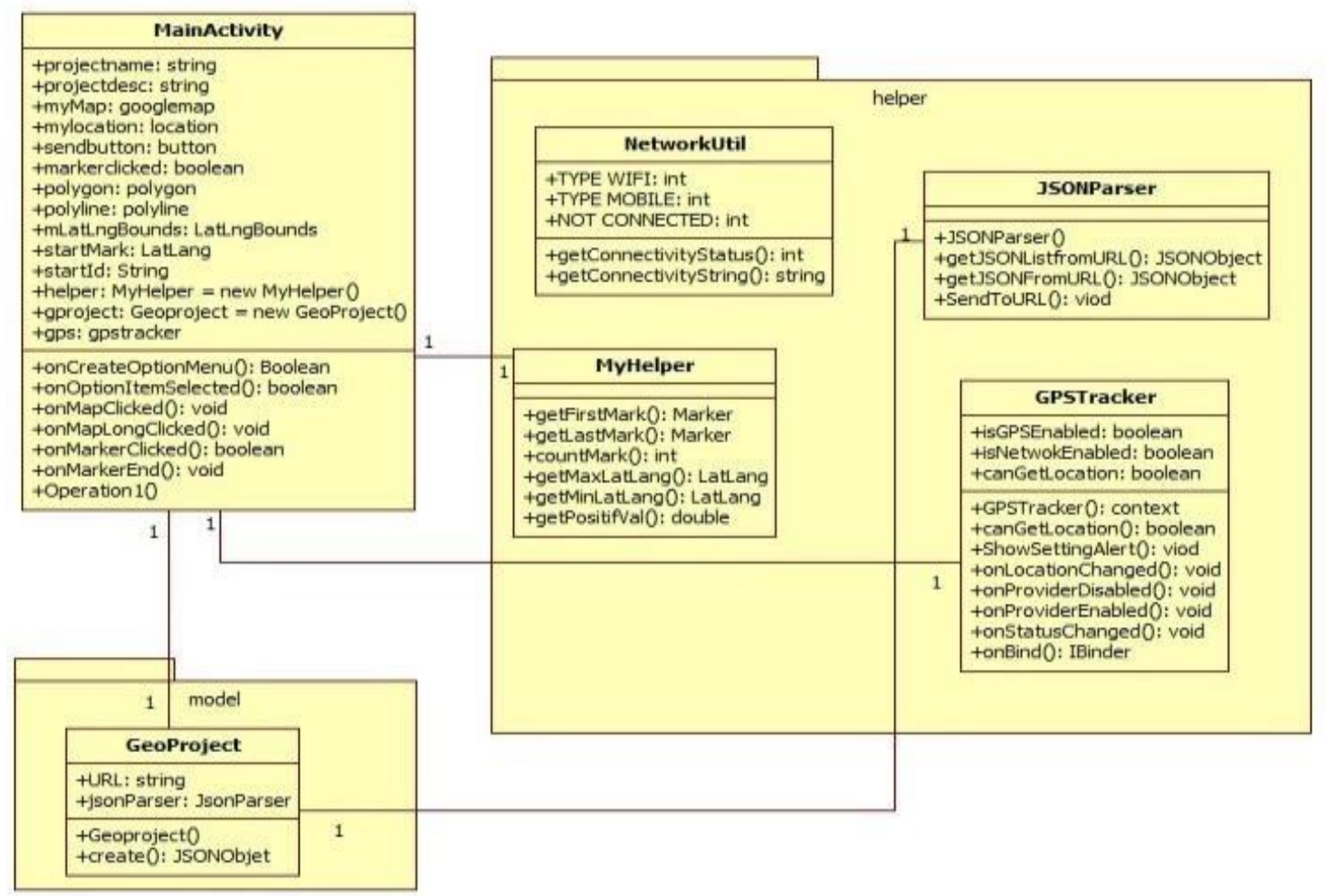

Gambar 3. Perancangan Navigasi Bagian Website (Crawford \& Mort, 2017)

Tabel 1. Koordinat lokasi beserta gambar lokasi banjir Kota Samarinda

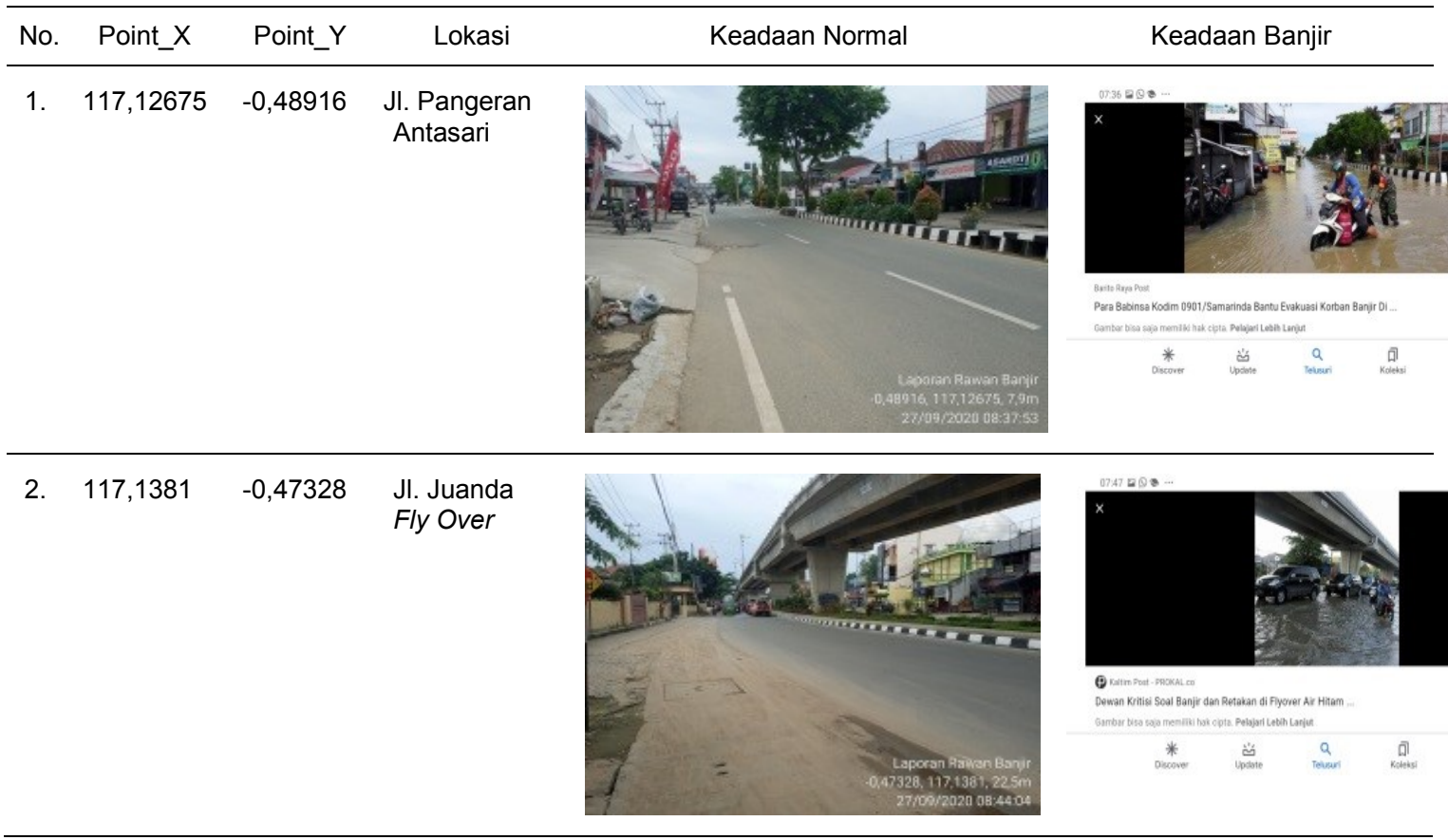




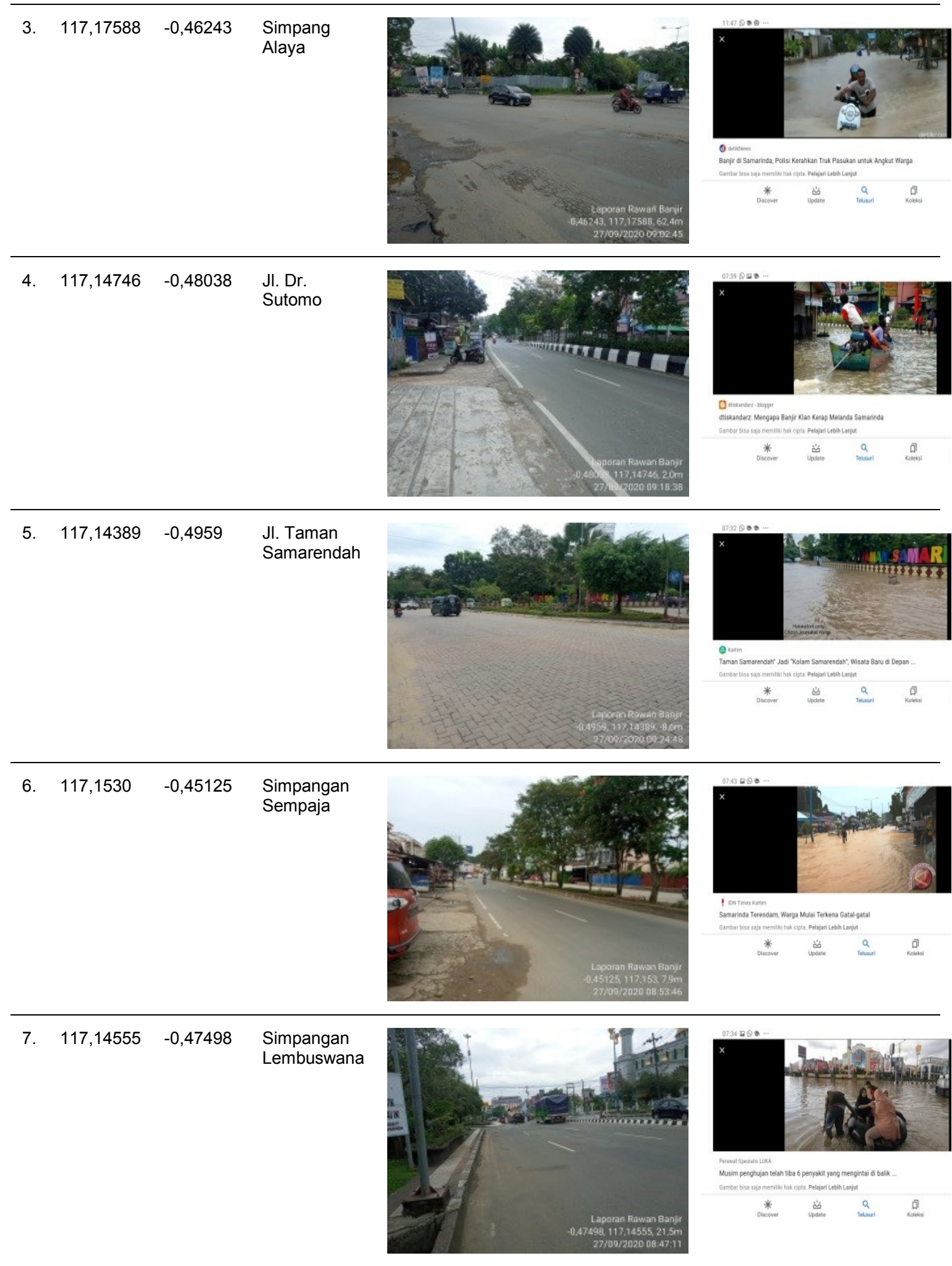


Cara memulai.

- Pasang baterai.

- Aktifkan perangkat dengan menekan tombol (Light) yang berwarna merah.

- Mencari satelit lanjut pilih menu satelit di layar utama lanjut cari tempat yang terbuka agar cepat dan mudah menangkap sinyal. Selanjutnya, diamkan untuk beberapa saat untuk mencapai akurasi maksimum satelit.

Pengaturan GPS Garmin 78S.

- Pilihlah (Setup) atau pengaturan di layar utama.b. Selanjutnya akan muncul menu lainnya dari pengaturan. Sistem lanjut GPS (Normal) lanjut Bahasa (Indonesia) lanjut tipe baterai (Lithium/Alkaline/NiMH) lanjut Interface (Garmin Serial).

- Tampilan lanjut waktu kecerahan layar disesuaikan dengan kebutuhan lanjut Battery save (on/off) lanjut warna disesuaikan dengan kebutuhan.

- Jejak lanjut log jejak (do not record/tidak merekam) lanjut metode rekam (otomatis)

\section{Peta Sebaran Banjir Kota Samarinda 2020}

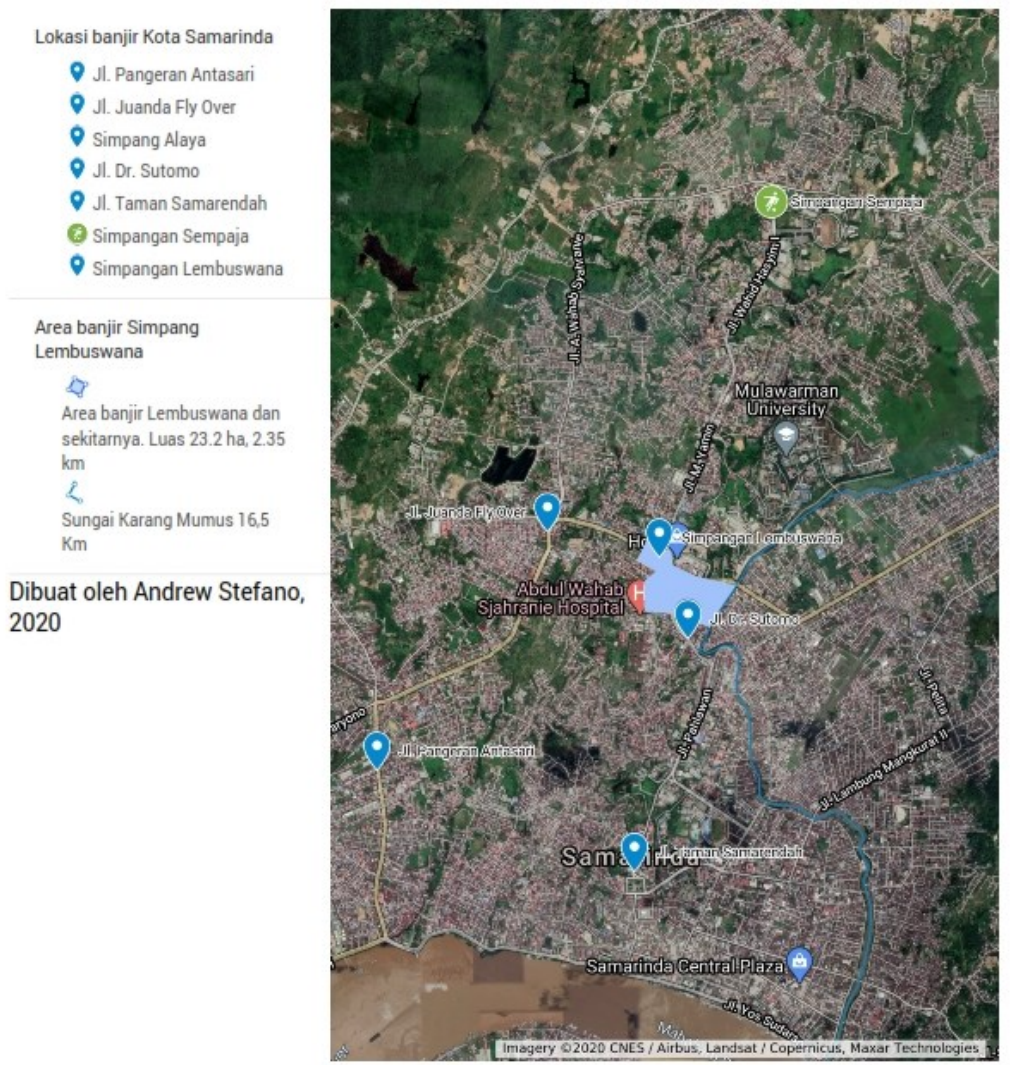

Gambar 4. Peta sebaran banjir Kota Samarinda

Satuan lanjut Jarak/kecepatan (Metrix) lanjut ketinggian (Meter, $\mathrm{m} / \mathrm{s}$ ) lanjut kedalaman (Meter) lanjut Suhu (Celcius) Lanjut Tekanan (Milimeter Hg). Waktu lanjut format waktu (24 jam) lanjut zona waktu (Bangkok,Hanoi dan Jakarta). Format posisi lanjut format posisi (UTM) lanjut Datum peta (WGS 83). Kalibrasi GPS adalah dengan melakukan putaran 2 kali secara pelan-pelan ke arah kanan. Dan GPS akan mengkalkulasi sinyal dari satelit stasioner di atasnya, untuk menentukan arah kompas dengan benar.

Penggunaan GPS Garmin 78S.

- Waypoint Marking adalah memperoleh koordinat dari suatu titik lokasi yang di survey. Dengan cara menekan tombol Enter dilanjutkan dengan tombol OK dan dilanjutkan dengan tombol Save.

- Tracking dalam peristilahan GPS adalah 
melakukan akuisisi data koordinat secara otomatis berdasarkan jalur yang kita lalui dan data tersebut disimpan dalam kartu memori GPS secara otomatis pula. Untuk memulai tracking tekan tombol menu dua kali, maka akan muncul Menu Utama, pilih track, tekan Enter.

Untuk menyimpan hasil tracking dalam sebuah nama, tekan enter setelah kursor berada pada button Save. Anda bisa mengubah nama atau membiarkan nama default. Pada saat menyimpan ini anda akan diberi pilihan menyimpan seluruh track, atau menyimpan track yang baru saja anda lakukan. Untuk menampilkan dalam peta GPS klik pada salah satu dari daftar track yang ada. Pilih Map/maka peta dengan tracking yang anda lakukan akan muncul.

Route/ Rute dalam peristilahan GPS adalah melakukan akuisisi data koordinat (harus berupa titik) secara otomatis berdasarkan jalur yang kita lalui dan data tersebut disimpan dalam kartu memori GPS secara otomatis pula. Disinilah letak perbedaan antara Track dan Route. Kalau dalam Track tidak dipersyaratkan menentukan titik yang akan diambil, sedangkan dalam Route diharuskan mencari/menentukan titik terlebih dahulu (karena Route digunakan untuk membuat Polygon).

Peta kemudian dibuat dalam format print dengan cara klik tanda titik tiga disamping kanan judul peta, lalu pilih cetak peta. Atur ukuran kertas dan format hasil keluaran (Gambar 4). Berdasarkan dari hasil evaluasi pengujian perangkat lunak diatas maka menghasilkan kesimpulan bahwa Aplikasi Perhitungan Luas Tanah ini sudah berjalan secara fungsional dan memberikan informasi sesuai dengan yang diharapkan apabila tidak ada gangguan dalam koneksi internet. Aplikasi ini tidak berjalan dengan baik apabila ada ganguan dengan koneksi internet, sebagai contoh: aplikasi tidak dapat menangkap titik koordinat dan data tidak dapat dikirim ke web server.

\section{KESIMPULAN}

Berdasarkan pembahasan tersebut dapat diambil kesimpulan sebagai berikut: Pemanfaatan GPS dalam smartphone dapat digunakan untuk menghitung luas tanah dengan bantuan Aplikasi Tambahan, Menghitung Luas Tanah menggunakan Aplikasi GPS pada smartphone dapat menghemat biaya selama proses perhitungan, Akurasi ketepatan data dari proses perhitungan ini adalah $83 \%$. Hal ini dapat berjalan dengan baik apabila terkoneksi dengan internet.

\section{UCAPAN TERIMAKASIH}

Penelitian ini didanai dari Sertivikasi Dosen Kementerian Ristek DIKTI Tahun 2020.

\section{DAFTAR PUSTAKA}

Abdolkarimi, E. S., Abaei, G., Selamat, A., \& Mosavi, M. R. (2020). A hybrid Type-2 Fuzzy Logic System and Extreme Learning Machine for low-cost INS / GPS in high-speed vehicular navigation system. Applied Soft Computing Journal, $\quad 94, \quad 106447$. https://doi.org/10.1016/j.asoc.2020.106 447

Barefoot, C. R., Willson, K. G., Hart, J. L., Schweitzer, C. J., Dey, D. C., \& Service, U. F. (2019). Forest Ecology and Management Effects of thinning and prescribed fire frequency on ground flora in mixed Pinus -hardwood stands. Forest Ecology and Management, 432(September 2018), 729-740. https://doi.org/10.1016/j.foreco.2018.09. 055

Crawford, D. J., \& Mort, M. E. (2017). Island ontogenies, syngameons, and the origins and evolution of. Journal of PPEES

Sources. https://doi.org/10.1016/j.ppees.2017.03. 003

Dorothea, C., Wilson, P., \& Hauskov, A. (2020). Patient Education and Counseling Dealing with parental concerns: A study of GPs â $€^{\mathrm{TM}}$ practice. Patient Education and Counseling, 2019. https://doi.org/10.1016/j.pec.2020.04.02 8

Elsaied, H. E., Soliman, T., Abu-taleb, H. T., Goto, H., \& Jenke-kodam, H. (2019). Ecological Genetics and Genomics Phylogenetic characterization of eukaryotic and prokaryotic gut flora of 
Nile tilapia, Oreochromis niloticus, along niches of Lake Nasser, Egypt, based on rRNA gene high-throughput sequences. Ecological Genetics and Genomics, 11(February), 100037. https://doi.org/10.1016/j.egg.2019.1000 37

Grobler, B. A., Cawthra, H. C., Potts, A. J., \& Cowling, R. M. (2019). Plant diversity of Holocene dune landscapes in the Cape Floristic Region: The legacy of Pleistocene sea-level dynamics. Quaternary Science Reviews, $x x x x$, 106058.

https://doi.org/10.1016/j.quascirev.2019 106058

Huang, H., Liao, J., Zhang, Z., \& Zhan, Q. (2017). Plant Diversity Ex situ Flora of China. Plant Diversity, 39(6), 357-364. https://doi.org/10.1016/j.pld.2017.12.00 1

Jamil, M., Murtaza, G., Shaheen, H., \& Habib, T. (2020). Distribution pattern and associated $\mathrm{fl}$ ora of Jurinea dolomiaea in the western Himalayan highlands of Kashmir: An indicator endemic plant of alpine phytodiversity. Ecological Indicators, 116(December 2018), 106461. https://doi.org/10.1016/j.ecolind.2020.1 06461

Janicka, M., Kutkowska, A., \& Paderewski, J. (2020). Diversity of vascular fl ora accompanying Salix viminalis $L$. crops depending on soil conditions. Global Ecology and Conservation, 23, e01068. https://doi.org/10.1016/j.gecco.2020.e0 1068

Kadereit, J. W. (2017). The role of in situ species diversification for the evolution of high vascular plant species diversity in the European Alps - a review and interpretation of phylogenetic studies of the endemic flora of the Alps. Journal of PPEES Sources. https://doi.org/10.1016/j.ppees.2017.03. 002

Katapally, T. R., Bhawra, J., \& Patel, P. (2020). Health and Place A systematic review of the evolution of GPS use in active living research: A state of the evidence for research, policy, and practice. Health and Place, 66, 102453. https://doi.org/10.1016/j.healthplace.20 20.102453
Khan, M. N., Badshah, L., \& Muhammad, S. (2018). Acta Ecologica Sinica Floristic Diversity and utility of $\mathrm{fl}$ ora of district Charsadda, Khyber Pakhtunkhwa. $x x x x$.

https://doi.org/10.1016/j.chnaes.2018.1 0.003

Lißner, S., Huber, S., Lindemann, P., Anke, J., \& Francke, A. (2020). Transportation Research Interdisciplinary Perspectives GPS-data in bicycle planning: "Which cyclist leaves what kind of traces?" Results of a representative user study in Germany. Transportation Research Interdisciplinary Perspectives, 7, 100192.

https://doi.org/10.1016/j.trip.2020.10019 2

Liu, S., Pan, J., Meng, X., Zhu, J., \& Zhou, J. (2019). ScienceDirect Trichinella spiralis infection decreases the diversity of the intestinal flora in the infected mouse. Journal of Microbiology, Immunology and Infection, $x x x x$. https://doi.org/10.1016/j.jmii.2019.09.00 9

Lizurek, G., \& Crespi, M. (2021). High-rate GPS positioning for tracing anthropogenic seismic activity: The ' $w$ Copper District, Poland 29 January 2019 mining tremor in Legnica- G † og o. 168(August 2020), 1-9. https://doi.org/10.1016/j.measurement.2 020.108396

Mascitelli, A., Federico, S., Torcasio, R. C., \& Dietrich, S. (2020). ScienceDirect Assimilation of GPS Zenith Total Delay estimates in RAMS NWP model: Impact studies over central Italy. Advances in Space Research, xxxx. https://doi.org/10.1016/j.asr.2020.08.03 1

Poliziani, C., Rupi, F., Mbuga, F., Schweizer, J., \& Tortora, C. (2020). Research in Transportation Business \& Management Categorizing three active cyclist typologies by exploring patterns on a multitude of GPS crowdsourced data attributes. Research in Transportation Business \& Management, August, 100572. https://doi.org/10.1016/j.rtbm.2020.1005 72

Prikryl, P., Weygand, J. M., Ghoddousi-fard, R., Jayachandran, P. T., \& Themens, D. 
R. (2020). Temporal and spatial variations of GPS TEC and phase during auroral substorms and breakups. Polar Science, April, 100602. https://doi.org/10.1016/j.polar.2020.100 602

Shimna, K., \& Muthu, M. S. (2020). Journal of Atmospheric and Solar-Terrestrial Physics Detecting ionospheric disturbances using GPS without aliasing caused by non-uniform spatial sampling: Algorithm, validation and illustration. Journal of Atmospheric and Solar-Terrestrial Physics, 209(August), 105400.

https://doi.org/10.1016/j.jastp.2020.105 400

Si, H., Yang, Q., Hu, H., Ding, C., Wang, H., \& Lin, X. (2020). Seminars in Cancer Biology Colorectal cancer occurrence and treatment based on changes in intestinal $\mathrm{fl}$ ora. Seminars in Cancer Biology, May, 0-1. https://doi.org/10.1016/j.semcancer.202 0.05 .004

Sophia, L., Pratama, C., \& Widjajanti, N. (2020). Geodesy and Geodynamics Spatiotemporal variation of vertical displacement driven by seasonal hydrological water storage changes in Kalimantan , Indonesia from GPS observation. Geodesy and Geodynamics, 11(5), 350-357. https://doi.org/10.1016/j.geog.2020.06.0 03

Svetlana, P., Torsten, U., Anna, A., \& Valentina, T. (2019). Plant Diversity Early Miocene $\mathrm{fl}$ ora of central Kazakhstan ( Turgai Plateau ) and its paleoenvironmental implications. Plant Diversity, 41(3), 183-197. https://doi.org/10.1016/j.pld.2019.04.00 2

Teickner, H., Knoth, C., Bartoschek, T., Kraehnert, K., Vigh, M., Purevtseren, M., Sugar, M., \& Pebesma, E. (2020). Patterns in Mongolian nomadic household movement derived from GPS trajectories. Applied Geography, 122(January),

102270. https://doi.org/10.1016/j.apgeog.2020.1 02270

Uehara, O., Hiraki, D., \& Kuramitsu, Y. (2020). ScienceDirect Alteration of oral flora in betel quid chewers in Sri Lanka.
Journal of Microbiology, Immunology and Infection, $x x x x$. https://doi.org/10.1016/j.jmii.2020.06.00 9

Verdú, M., Pausas, J. G., Postigo-mijarra, J. M., Barrón, E., Casas-gallego, M., \& Arroyo, J. (2019). Phylogenetic diversity in the Iberian $\mathrm{fl}$ ora through the Cenozoic. Environmental and Experimental Botany, September, 103888.

https://doi.org/10.1016/j.envexpbot.201 9.103888

Wang, B., \& Wang, X. (2019). Species diversity of fecal microbial $\mathrm{fl}$ ora in Canis lupus familiaris infected with canine parvovirus. Veterinary Microbiology, 237(August), 108390. https://doi.org/10.1016/j.vetmic.2019.10 8390

Wang, Q., Jin, S., \& Hu, Y. (2020). Estimation of QZSS differential code biases using QZSS / GPS combined observations from MGEX. Advances in Space Research. https://doi.org/10.1016/j.asr.2020.10.04 9

Woldemariam, W., Mekonnen, T., Morrison, K., \& Aticho, A. (2018). Journal of AsiaPaci fi c Biodiversity Assessment of wetland $\mathrm{fl}$ ora and avifauna species diversity in Kafa Zone, Southwestern Ethiopia. Journal of Asia-Pacific Biodiversity, 1-9. https://doi.org/10.1016/j.japb.2018.08.0 03

Xie, Y., Liu, H., Li, H., Tang, H., Peng, H., \& $\mathrm{Xu}, \mathrm{H}$. (2020). High-effectively degrade the di- ( 2-ethylhexyl ) phthalate via biochemical system : Resistant bacterial $\mathrm{fl}$ ora and persulfate oxidation activated by BC@Fe 304 *. Environmental Pollution, 262, 114100. https://doi.org/10.1016/j.envpol.2020.11 4100

Ye, J., Lu, L., Liu, B., Yang, T., Zhang, J., $\mathrm{Hu}, \mathrm{H}$., Lu, A., Liu, H., Mao, L., \& Chen, Z. (2019). Molecular Phylogenetics and Evolution Phylogenetic delineation of regional biota: A case study of the Chinese fl ora. Molecular Phylogenetics and Evolution, 135(February), 222-229. https://doi.org/10.1016/j.ympev.2019.03 .011 
Yi, Z., Xia, Y., Liu, X., Wang, G., Xiong, Z., \& Ai, L. (2020). Antrodin A from mycelium of Antrodia camphorata alleviates acute alcoholic liver injury and modulates intestinal flora dysbiosis in mice. Journal of Ethnopharmacology, 112681. https://doi.org/10.1016/j.jep.2020.11268 1

Zhang, L., Gui, S., Wang, J., Chen, Q., Zeng, J., Liu, A., Chen, Z., \& Lu, X. (2020). Oral administration of green tea polyphenols ( TP ) improves ileal injury and intestinal $\mathrm{fl}$ ora disorder in mice with Salmonella typhimurium infection via resisting in $\mathrm{fl}$ ammation, enhancing antioxidant action and preserving tight junction. Journal of Functional Foods, 64(November 2019), 103654. https://doi.org/10.1016/j.jff.2019.103654

Zhu, S., Yue, D., He, L., Liu, Z., \& Chen, J. (2020). ScienceDirect Comprehensive analysis of compatibility between QZSS and GPS in Asia-Pacific region: Signal quality , RTK and PPP. Advances in Space Research, 2023(October 2017). https://doi.org/10.1016/j.asr.2020.04.00 3 